\title{
The Effects of Industry Specialization on Auditor's Opinion in Iran
}

\author{
Mahdi Omidfar* \\ Ph.D student, Accounting, Ferdowsi University of Mashhad, Iran \\ *Corresponding Author: Mahdi.omidfar@stu.um.ac.ir
}

Mahdi Moradi

Associate Professor of Accounting, Ferdowsi University of Mashhad, Iran

mhd_moradi@um.ac.ir

\section{Doi:10.5901/mjss.2015.v6n1p399}

\begin{abstract}
The current study aims to provide evidences regarding the audit industry expertise as one of the criteria of auditing quality. For this purpose, in this research the relation between audit industry expertise and auditor's type of opinion is studied using the financial information extracted from listed companies in Tehran Stock Exchange during 2004 - 2012. The previous studies indicated the positive effect of this criterion on quality of auditing in companies. To support the evidences of the former studies, after control of other relevant environmental factors, the results of this study showed that there is a positive and significant relation between audit industry expertise and auditor's qualified opinions. The obtained evidences supported this idea that audit firm specialization could lead to improved quality of financial information of the capital market. Regarding other used variables of the research, the results showed that the auditor size and return of assets negatively, and the company's size and performance of the previous year positively are dependent on the type auditor's opinion. The results of this study add to the literature of audit quality through study of the role of audit industry expertise as well as the study of the relevant factors to the type of auditor's opinion.
\end{abstract}

Keywords: Auditing Quality, Auditor's Opinion, Audit Industry Expertise, Company's Performance.

\section{Introduction}

Audit quality determines the auditing performance. It depends on different factors including auditor's abilities (including knowledge, experience, adjustment power and technical efficiency) and his professional implementation (including independence, objectivity, professional care, conflict of interests and judgment). The quality structure of auditing is multidimensional and intangible. For this reason its measurement is very difficult. Since different factors affect the quality of auditing, it is considered as an important element to determine a framework for specifying the audit quality. Many researches were conducted regarding the effective factors on auditing quality out of which the audit size (DeAngelo, 1981; Feroz et al., 1991; Teoh and Wong, 1993; Becker et al., 1998), auditing industry expertise and auditor' reputation (Beattie and Fearnley, 1998) and auditing rotation (Azizkhani et al., 2013) could be named. Independent auditors play a vital role in the process of financial reporting that could impede management to use accounting policies very boldly and consequently it leads to higher quality financial statements. The studies showed that audit industry expertise improves the company's financial reporting quality due to more expertise in the employer's industry (Balsam et al., 2003; Krishnan, 2003). Industry experts are the auditors that have high education and a lot of experience and are concentrated on a specific industry (Solomon et al., 1999). Experimental studies showed that auditors, having knowledge about one special industry have higher and more comprehensive understanding of the specifications of a company and this increases the abilities and methods to recognize errors (Maletta and Wright, 1996; Owhoso et al., 2002). Following a series of obtained results regarding the role of industry expert auditors, we imagine that the companies that use expert industry auditors have higher auditing quality.

We at the current study aim at investigating the effect of audit industry expertise on the auditing quality using the criterion of the type of auditing report (according to Ballesta, and Garcia-Meca, 2005) in the capital market of Iran. The results of the study could help the theoretical literature of the study of auditing quality from two dimensions, i.e., study of the role of audit industry expertise as well as study of the effective factors on auditor's preferred opinions. Also the results of the study could be effective on the policy-makers of the capital market to compile auditing regulations to improve the 
quality of effective auditing organizations. The results of the testing the research hypothesis using logistic regression method indicated that audit industry expertise could affect the auditing quality in capital market of Iran. The rest of this paper has five parts as follows. In the first part, the theoretical literature of the study was focused on. Then the research background and hypothesis was expanded. In the third part, the research method was presented. This was followed by a presentation of the descriptive statistical expression in addition to the results of the study and eventually the paper came to an end by drawing a conclusion and presenting suggestions.

\section{Theoretical Grounds of the Study}

\subsection{Auditing quality}

There have been many definitions given for the auditing quality, although different, but they follow the same structure. Wallace (1980) found the auditing quality a reduction of impurities and an improvement of the purity degree of accounting data. According to DeAngelo (1981), auditing quality consists of two possibilities: Firstly that the auditor could detect the important alterations made to the employer's financial statements or accounting system and secondly to report them. According to Etemadi et al., (2009) the auditor could detect the important alterations, depending on his qualification and could report these detected important alterations depending on his independence.

Wallace (1980) studied the request for auditing services in free markets and the markets under supervision and identified three separate but related sources of request for auditing services and introduced them within the framework of three hypotheses:

1. Representation hypothesis: This hypothesis finds demand for auditing caused by conflict of interests among directors (business holder), shareholders (employer), creditors, labor unions, etc. This hypothesis shows that auditor could reduce the representation costs by autonomous behavior of the employers.

2. Information hypothesis: In the area of information hypothesis, it is thought that reason supporting investors' demand as a group of users of audited financial statements means that the mentioned financial statements present useful information for relevant decision-making of the investors. This hypothesis indicates that auditing reduces the information risk of company.

3. Insurance hypothesis: According to this hypothesis, investors and creditors are insured by auditor's professional responsibilities against insured financial losses.

Two initial roles of auditing show that higher quality auditing leads to reduction of company's investment cost (from technical auditing aspect) and the third role of auditing shows that auditor's more financial resources will result in reduced investment costs of the company (compensational aspect of auditing). The quality specifications of auditing could be classified as the quality specifications of auditing including size and expertise of audit industry and the quality specification concerning the relation between business holder and auditor during the term of the auditor's responsibility. Contrary to most goods and services, direct evaluation of audited financial statements is difficult. Since it is difficult to observe the quality of the auditors' work, different criteria were introduced to assess the auditing quality by researchers (for further information, see Vanstraelen, 2000). The evidences indicate that the industry expert auditors present more effective auditing. Also the structural changes made to the auditing organizations to achieve industrial expertise show that industrial expertise plays an important role in auditing quality (Balsam et al., 2003; Krishnan, 2003).

\subsection{Audit Industry Expertise}

According to Kend (2008) auditing expertise in industry consists of developing constructive ideas in order to help the employers to create added value in addition to provision of approaches and or new actions for some of the subjects that the employers are faced with in the relevant industries to them. Auditors should do the following in order to be able to be known as audit industry experts: 1) to know special industrial issues and to understand them, 2) to know key organizations in that industry, 3) to be active in that industry, 4) to be aware of the effectiveness of special industrial issues on different sectors of industry. Despite the fact that a lot of attention was paid in recent years to the issue of audit industry expertise, Neal and Riley (2004) believe that there is no unique criterion to measure audit industry expertise. The two initial criteria to identify audit industry expertise are the market share approach and profitable share approach in addition to the fact that this is a new mixed criterion which depends on the market share and the profitable share. 


\subsubsection{Market Share approach}

According to market share approach, an industry expert auditor is the audit organization that is distinguished from other competitors as far as the market share in a specific industry is concerned (Balsam et al, 2003, Dunn and Mayhew, 2004). This approach assumes that the degree of audit industry expertise of the auditing organizations could be found out by observing the relative share of the market of auditing organizations that provide a special industry with services. An organization that has a higher share of the market has a higher expert knowledge regarding that industry too.

\subsubsection{Profitable Share Approach}

Profitable share approach considers a relative distribution of auditing services in different industries for each auditing organization. To explain it in more simple words, every auditing organization has employers that form its profitable share. The industry that has more employers as far as sale, entire assets, etc. are concerned, has more profit which shows an industry where the auditing organization has expertise in that area. This approach is based on the fact that every industry is very important for the employer's total profit (Krishnan, 2003). The third criterion which is suggested for audit industry expertise is a mixed criterion that mixes the profitable share and market share together (Neal and Riley, 2004).

Kimberly et al., (2004) believed that auditors want to acquire expertise to deal with active companies in one industry to be able to establish a kind of distinction between them and other auditors. Existence of this distinction will provide the auditors with the possibility to enjoy two simultaneous options of lower price and higher quality of services (better disclosure quality) instead of only one attractive option (lower price to do auditing) in order to attract the attention of the general assemblies of the shareholders, and in practice the employing companies seek expert auditors for several reasons. One of these reasons is to reduce costs because using expert auditors saves costs more than the saved costs from using other auditors. This is because auditing reviews a high share of the companies of one industry (by expert auditor in that industry) and due to their former experience, they save costs in the saving scale in comparison with the other auditors; therefore, under normal circumstances, they receive lower fees in comparison with the other auditors. The other reason is that it is expected that this type of auditors present better consultation and guidance with regard to provision and disclosure of information and they take more suitable corrective actions to remove the problems and issues with the accounting and financial reporting process.

\section{Related Literature and Hypothesis}

Fernando et al., (2010) studied the effect and quality characteristics of auditing (size of auditing company, audit industry expertise and auditor's term) on the costs of shareholders' equity of the company. They showed in this study that there is a negative relation between the size, industry expertise and auditor' term and the costs of employer's and shareholders' equities. In other words, increased quality of auditing reduces the costs of the shareholders' equity of the company. Ahmadpour et al., (2010) studied experimentally the effect of company's governance and auditing quality on the costs of receiving credits from the companies active in Tehran Stock Exchange Market. The experimental findings using the information of 119 companies recognized by Tehran Stock Exchange Market between 2003 and 2008 and regression analysis of the research data showed that the existence of major institutional shareholders among the shareholders and proved that their efficient supervision has a significant reducing effect on the debt costs of the member companies of the sample, while the auditing quality does not have such an effect. Hajiha and Sobhani (2012) found out that the companies whose auditor is expert in the industry have less investment costs and lower interest rate in comparison with the companies that do not use audit industry experts, Also Hassasyeganeh et al., (2012) found out that there is no significant difference between information content of withheld and cash components of profit in the companies that use industry expert auditors in comparison with the other companies. At the same time, there is a trend of former auditing researches that study the effect of audit industry experts on the quality of financial reporting. The studies that were conducted in the area of auditing quality show that there is a positive relation between the type of industry that auditors have expertise about and the quality of the audit industry reports. Auditors that are expert in a special industry are able to conduct a better quality auditing as they are more capable to identify and treat the special problems of that industry. In addition, the more experienced the auditing organization in one industry is, the more interested it will be to present higher quality auditing services to create positive reputation (see Hassassyeganeh et al., 2013).

In this regard, Reichelt and Wang (2010) showed that the audited companies by the experts of the industry have lower withheld items and receive the opinions about continued activity more likely. Shirinbakhsh et al., (2013) showed that audit industry expertise reduces unbalanced information. Balsam et al., (2003) as well as Etemadi et al., (2009) 
found out that the employers and industry expert auditors have lower profit management and higher profit reaction coefficient. At the same time in another study, Etemadi et al., (2010) showed that the companies manage real profit despite having industry expert auditors. They justify that the companies manage the actual profits to achieve their goals after becoming disappointed to manage the optional withheld items so that they make the industry expert auditors disappointed to detect profit management. With regard to restatement $s$ also, the results of the former studies indicate the positive effect of auditors' industry expertise on reduction of restatements (Stanley and DeZoort, 2007; Bloomfield and Shackman, (2008; Ramanus et al., 2008; Baber et al., 2010). For example, Ramanus, et al., (2008) found out that the audited companies by industry experts' show less inclination to re-present accounting items in comparison with audited companies by non-experts. They also found out that changing one non-expert auditor to an expert auditor increases the possibility of restatements and vice versa. Owhoso et al., (2002) showed that industry experts could detect the mistakes made during a fiscal period by the experts through auditing process. Low (2004) found out that the audit industry expertise improves the assessment of auditing risk. These studies of auditing behavior show that the audit industry expertise could increase the effectiveness of the auditors' job as a result of a specific industrial knowledge. Generally speaking, according to the former studies, the audit industry expertise has different results including timely presentation of auditing report (Habib and Boeian, 2011), improved quality of financial reporting (Dunn and Mayhew. 2004), less restatement of financial information (Romanus et al., 2008), improved quality of profit and reduced profit management (Krishnan, 2003; Balsam et al., 2003), improved profit prediction (Behn et al., 2008) and less inclination to meet the analysts' predictions (Payne, 2008). In fact the auditors have more ability to detect mistakes in industry as far as their expertise is concerned (Gul et al., 2009). The archived auditing studies show that the audit industry expertise improves the role of auditor in promoting the financial reporting quality and has positive effect on auditing quality. Thus the following hypothesis is presented.

Hypothesis: There is a positive and significant relation between audit industry expertise and auditing quality.

\section{Research Method}

\subsection{Research Model}

In this study, to investigate the relation between audit industry expertise and the auditor's opinion, the following regression model was used. According to this model, the auditor's opinion of this year is considered as a dependent variable and the audit industry expertise variable is considered as the variable under study. To control the possible effects of the other factors that could affect (potentially) the auditor's opinion, some control variables were also added to the model that will be explained further on. The main model of the study is as follows:

$$
\begin{aligned}
& \text { Opinion }_{t}=\beta_{0}+\beta_{1} \text { Expert }_{t}+\beta_{2} \text { AuSize }_{t}+\beta_{3} \text { Switch }_{t}+\beta_{4} \text { PreOpin }_{t-1}+\beta_{5} \text { FmSize }_{t}+\beta_{6} L_{E V}+\beta_{7} W_{t}+\beta_{8} R_{\text {ROA }}+ \\
& \beta_{\text {LLOSSt }-1}+\beta_{\mathrm{k}} \sum_{k=10}^{18} \text { Years }+\beta_{j} \sum_{j=19}^{33} \text { Industries }+\varepsilon \text {. }
\end{aligned}
$$

\subsection{Research Variables}

Auditor Opinion is the dependent variable of the research. It is one, if the auditor's opinion of the current year is unacceptable and otherwise Zero. Auditor industry expertise is considered as the main variable of the research and a virtual variable which is equal to one is noted if the company's auditor in current year is an industry expert, otherwise zero. In this study, the auditor's industry expertise (according to Balsam et al, 2003) is defined with 10\% difference in comparison with the second organization according to the auditor in full command of each industry as far as the total audited sale income of the employers is concerned ${ }^{1}$. According to the former studies in this research in addition to the variables under study, other variables that could affect the auditor's opinion are also used as control variables. The first variable is the auditor's size (AuSize). In auditing literature, the fact that big auditing firms present a vaster level of auditing quality is widely accepted. This topic was approved by DeAngelo (1981) theoretically and by different criteria such as profit reaction coefficient (Teoh and Wong, 1993). DeAngelo (1981) reasoned that the auditors of big firms present a better quality of auditing in comparison with small firms. Piri et al., (2013) and also Hassasyeganeh and Azinfar (2010) found out that there is a positive and significant relation between the size of an auditing firm (measured by some employers as well as the auditing organization as the big organization) and profit management. Nonahal et al., (2010)

\footnotetext{
1 In other measurements in a sensitivity test, number of clients were also used to measure the audit industry expertise.
} 
found out that the audited companies by higher quality auditors have higher sustainability coefficients of withheld items and as a result the have a higher reliability of withheld items. According to Park (1990) and also Ireland (2003), a bigger auditing firm should be more resistance against the employers' imposed management because either the effect of the employer's pressure on these firms is not that high or the reputation and credit of the auditing firm will neutralize such pressure. Chi et al(2013) did not find any evidences that the BigN auditors have lost their independence when working with employers who run big economies, while such evidences was found in case of small auditing firms. Thus it is expected that there is a negative relation between the size of the auditing firm and provision of qualified opinion. Meanwhile, Li (2009) reported a positive relation. In this study according to most of the studies in Iran (Sajjadi et al., 2009), if the company's auditor is an auditing organization in the current year, figure one is given to it, otherwise zero. Change of auditor will be considered as the second control variable. Several studies show that change of auditor has an important effect on the quality of companies' reporting as well as the type of the auditor's opinion. Farber (2005) showed that change of auditor increases the possibility to have restatement of accounting. Chen et al., (2009) found out that there is a direct relation between the changes of auditor as an acceptable element of auditing reports. They showed that the directors change their auditors to show the company's performance as desirable. They aim to receive an acceptable report by the auditor by doing this change to demonstrate their performance as desirable. Banimahd (2011) found out that there is a direct relation between change of auditor (from a private auditing firm to another private auditing firm) and the acceptable report. Carey et al., (2008) in Australia found out that there is a direct relation between change of auditor and issue of unacceptable auditing report regarding the continued activity of the company. In another study, Baniahmad et al., (2013), using a sample company active in Tehran Stock Exchange Company between 2002 and 2010 found out that there is a direct relation between change of auditor and change of auditing opinion. Hence, it could be expected that the change of auditor reduces the chance of receiving undesirable report (qualified). In this study, it is one, if the company's auditor has changed in comparison with last year, figure one is given and otherwise zero (switch). Rezaei and Mousavian (2011) found out that there is a significant relation between delayed opinion given by the auditor and his current opinion. In another study conducted by Baqerpour et al., (2012), it was reported that the opinion given last year (PreOpin) by the auditor is part of the most important variables to predict the type of the opinion that will be given in the current year by an independent auditor. That is why a significant relation between opinion given by the auditor last year and the one given this year is expected. For this purpose, the company that has received an unacceptable opinion last year is given figure one and otherwise, it is defined by figure zero.

One of the other control variables is the company's size (FmSize). Several studies show that smaller companies are more likely to receive qualified opinions (Krishnan et al., 1996). According to the reasoning provided by Li (2009) bigger companies have more bargaining power in the process of auditors' decision-making. The results showed a negative relation between the size of company and the possibility to receive continued activity opinion. On the other hand, Agrawal and Chandha (2005) found out that the bigger companies are more likely to manipulate their financial statements. In this connection, Abbaszadeh and Manzarzadeh (2011) like Banimahd (2011) reported in the capital market of Iran that there is a negative relation between the company's size and the acceptable auditing report. In another study, Banimahd et al., (2013) reported a positive relation between the company's size and the auditor's changed opinion. That is why, a positive relation between the company's size and the unacceptable opinion of the auditor is expected. This variable was measured through natural logarithm of company's total sale? 2 .

Financial lever is the fifth control variable in this study which is an index to measure the company's financial risk (Chen et al., 2006). According to this approach, if the level of debts is high, it is more likely that the company presents wrong financial statements (Richardson et al, 2002). Li (2009) reported a positive relation between lever and qualified opinion. According to the study conducted by Baqerpour et al., (2012), the ratio of debt is considered as the most important variable to predict the auditor's opinion. Setayesh and Jamalianpour (2009) and also Rezaei and Mousavian (2011) found out that there is a significant relation between financial risk and independent auditor's opinion. According to results obtained by Li (2009) there is a positive relation expected from the relation between lever and auditor's unacceptable opinion. In this study, this variable (LEV) is calculated by dividing the total debts by the total assets at the end of each cycle. According to Li (2009), WC variable shows the cash risk of the company which is obtained by dividing the current assets by the current debts. He found out that the companies that receive opinion to continue activities have higher cash risk. Also Bloomfield and Shackman(2008) showed that there is a negative relation between cash level and profit management. Thus this variable was added to the model and its coefficient could be predicted in relation with the negative unacceptable opinion. Return of Assets (ROA) as a control variable has relation with the level of companies' profitability. Banimahd (2011), also Abbaszadeh and Manzarzadeh (2011) found out that there is a positive relation

${ }^{2}$ Due to inflation existing in Iran, the total figure of assets was not used. 
between the performance of management and the possibility of issuing an acceptable report. Also Jameie et al., (2012) stated that the improved performance of management reduces the issue of qualified reports. According to Li (2009) this variable shows the company's performance situation which is the result of dividing the net profit (loss) of the cycle by their total assets. According to the results, Li (2009) a negative relation for this variable is predictable.

According to Cao et al., (2009) and Chen et al., (2006) the companies that undertake loss try to improve it by making wrong presentation which is shown by restatement. Setayesh and Jamalianpour (2009) found out that there is a significant relation between the type of auditor's opinion and the type of performance. Li (2009) showed that there is a positive relation between non-profitability of the company and the auditor's unqualified opinion. Also Baniahmad et al., (2013) said that there is a negative relation between non-profitability of the company and auditor's changed opinion. According to the former researches, it is one, if the company reports about the loss at the end of the previous year figure one and otherwise zero, and it is expected that it has a positive relation with the auditor's unacceptable opinion. Profitability and loss situation variable is a virtual variable. If the company was not profitable last year, figure one and otherwise zero. Eventually, the year control variable (Years) consists of a set of virtual variables to control the effects of every year and the industry control variables (Industries) is composed of a set of virtual variables to control the effects of every industry. According to Geiger et al., (2005), the type of industry is one of the effective factors on the type of auditor's opinion. That is why using artificial variables; the effects relevant to industry and year are also controlled.

\subsection{Sample}

The statistical society of the current study is the recognized companies by Tehran Stock Exchange $t$ during a 9-year period from 2004 to 2012. To test the research hypothesis, logistic regression was used. The research data was collected from the database of Novin Rahavard as well as the financial statements of the companies using RDIS website. SPSS18 software was used to analyze the data. In this study, the sampling method was selected according to what most of studies conducted in Iran did out of the targeted unlikely sampling. In unlikely sampling plan, members of the statistical society were selected that corresponded with the researcher's special criterion or criteria. In this study, the sample started with the entire statistical society and after considering the following conditions, the sample was selected as follows:

The companies that had been recognized by the Stock Exchange before 2004.

The companies that did not change their fiscal year during the research term.

The companies that are not part of investment and holding (financial) companies.

The change of auditor is not obligatory according to the approval of the Supreme Council of Stock Exchange 3 .

The companies whose required information for research is available.

\section{Analysis of Research Results}

In this section, the research hypotheses are tested and analyzed. In order to test the research hypothesis, logistic regression was used and further on, firstly the descriptive statistics of the research variables and then the achieved results were discussed in detail.

\subsection{Descriptive Statistics}

Table 1 of the descriptive statistics shows the research variables. According to this table, $62 \%$ of the observations are based on qualified opinions. The mean of audit industry expertise is $30 \%$. Also this table shows that $23 \%$ of the sample of the auditing organization uses the title of their auditor and $20 \%$ of them use the changed auditor in this sample. The mean ratio of debt to assets in the capital market of Iran is about $70 \%$. Eventually it could be stated that the loss report of last year of the companies is roughly $8 \%$. Further on, the results of testing the research hypothesis are presented.

\footnotetext{
${ }^{3}$ According to this directive, auditing firms and partners in charge of auditing activity of each legal entity are not authorized to accept becoming the independent auditor or legal inspector of the mentioned company after four years again. 
Table 1. Descriptive Statistics of research variables

\begin{tabular}{lccccc} 
Variable & Std Dev. & Median & Mean & Max & Min \\
\hline Opinions & 0.485 & 1 & 0.62 & 1 & 0 \\
Expert & 0.473 & 0 & 0.3 & 1 & 0 \\
AuSize & 0.424 & 0 & 0.23 & 1 & 0 \\
Switch & 0.401 & 0 & 0.20 & 1 & 0 \\
PreOpi & 0.477 & 1 & 0.65 & 1 & 0 \\
FmSize & 1.253 & 12.60 & 12.72 & 16.82 & 9.41 \\
Lev & 0.222 & 0.670 & 0.686 & 1.667 & 0.187 \\
WC & 0.464 & 1.146 & 1.202 & 3.386 & 0.202 \\
ROA & 0.1227 & 0.0944 & 0.1086 & 0.5676 & -0.3479 \\
Loss & 0.275 & 0 & 0.08 & 1 & 0 \\
\hline
\end{tabular}

\subsection{Results of the Research Hypothesis}

Table 2 shows the results related to testing the research hypothesis which shows that there is a significant and positive relation between audit industry expertise and the type of auditor's opinion. The results reject the research hypothesis. In other words, there is no significant relation between audit industry expertise and the type of auditor's opinion. These results are according to the degree of sale by employers as the basis to measure the audit industry expertise. Meanwhile, the auditing was made in an additional test and using the criterion of the number of audited employers in each industry to support the research hypothesis which is presented in table 3. According to the obtained results, the results of this test showed that the audit industry expertise (according to the number of audited employers) is positively dependent on auditor's qualified opinion that shows the relative positive effect of audit industry expertise on the quality of auditing. This result is according to Reichelt and Wang (2010). Also it is in line with the results obtained by Krishnan(2003), Balsam et al(2003), Dunn and Mayhew(2004), Romanus et al(2008) and Eftekhari et al., (2009) regarding the quality of financial reporting.

Table 2. The results of research hypothesis's test

\begin{tabular}{lcccc} 
Variable & $\boldsymbol{\beta}$ & Standard Errors & Wald & P-Value \\
\hline Expert & .037 & .233 & .025 & .437 \\
Auditor & -.405 & .230 & 3.088 & .039 \\
SAudit & .043 & .206 & .044 & .416 \\
PerOpin & 2.006 & .161 & 156.069 & .000 \\
Size & .161 & .081 & 3.940 & .023 \\
Gear & .266 & .682 & .152 & .348 \\
Liq & -.241 & .242 & .990 & .160 \\
ROA & -3.793 & 1.002 & 14.333 & .000 \\
Loss & 1.562 & .577 & 7.330 & .003 \\
Constant & -.332 & 1.642 & .041 & .420
\end{tabular}

Regarding the research control variables, the results of table 2 as well as table 3 show that there is a negative and significant relation between the type of auditing according to the research prediction and the type of auditor's comment. In fact, in big auditing organizations, the possibility to issue qualified auditing opinion is less and this result corresponds with the results obtained by Hassasyeganeh and Azinfar (2010), Nonahalnahr et al., (2010) and Piri et al., (2013). Regarding the auditor's opinion of the previous year, the results were according to the old researches (Rezaei and Mousavian, 2011; Baqerpour et al., 2012) and research prediction. The results show that the auditor's qualified opinion of the previous year positively depends on the possibility to receive the qualified opinion in the current year. Regarding the other control variables, the results show that the company's size and the report of the loss of the previous year is positively and the return of assets is negatively dependent on receiving the auditor's opinion. In other words, in bigger companies and the companies that reported net loss in the previous year, the possibility of reporting auditor's qualified opinion is higher and in the companies that had better profitability, this possibility is lower. The results are different from the former studies as 
far as change of auditor variable is concerned. Meanwhile the coefficient of this variable was positive, but no significant relation was located between this variable and the auditor's qualified opinion. This result is in contradiction with most of the studies which show that the change of auditor is negatively dependent on receiving auditor's qualified opinion (Chena et al., 2009, Banimahd, 2011; Banimahd et al., 2013).

Table 3. The results of additional test

\begin{tabular}{lcccc} 
Variable & $\boldsymbol{\beta}$ & Standard Errors & Wald & P-Value \\
\hline Expert & .391 & .228 & 2.937 & .043 \\
Auditor & -.686 & .266 & 6.642 & .005 \\
SAudit & .062 & .206 & .092 & .381 \\
PerOpin & 2.011 & .161 & 156.005 & .000 \\
Size & .170 & .077 & 4.921 & .013 \\
Gear & .265 & .683 & .150 & .349 \\
Liq & -.245 & .243 & 1.018 & .156 \\
ROA & -3.792 & 1.006 & 14.209 & .000 \\
Loss & 1.549 & .578 & 7.175 & .003 \\
Constant & -.528 & 1.626 & .105 & .373
\end{tabular}

\section{Discussion and Conclusion}

In this research, using a set of control variables, the relation between audit industry expertise and auditor opinion was studied. The goal of this study was to find the answer to the question whether audit industry expertise could improve the quality of auditor's opinion in the capital market of Iran. To answer this question, two criteria of amount of audited sale and the number of employers of every auditing firm in each industry to measure the audit industry expertise were used. The results of the study showed that audit industry expertise (according to the criterion of the number of clients) is positively dependent on the type of auditor's report (qualified opinion) that according to the other conducted studies was rejected. The positive effect of this mechanism on auditing quality in the capital market of Iran was shown. Regarding the other variables of the study, also, the results showed that the size of the auditing firm and the return of assets negatively depend on the type of sensitive opinion. In other words, in a bigger auditing firm and also the companies that have better profitability, the possibility to issue auditor's qualified opinion reduces. Also the evidences show that the size of the company also depends on the type of sensitive opinion. In fact the bigger companies and also the companies that experienced net loss in the previous year will most likely receive the auditor's qualified opinion.

With regard to the performance variables, the obtained results are according to the findings of Jameie et al(2012). They reported that the stability of management at senior level and high profitability that is owned by the shareholders increase the possibility to receive an acceptable report. On this basis, it is suggested that the other potential effective factors on auditor's opinion are studied from a practical, management and ownership perspective. The results of this study increase the literature of the study of the auditing quality by investigating the role of audit industry expertise and also review of the relevant factors to the type of auditor's opinion. Conducting studies in this area could help promote the financial reporting, information transparency and eventually allocation of optimal resources in the capital market. The results of the study also help the policy-setters of capital market to know the effective factors on auditing quality.

\section{References}

Abbaszadeh, M.R, Manzarzadeh, H, (2011). "Study of possibility to issue acceptable report by independent auditors using characteristics of Board of Directors of companies recognized by Tehran Stock Exchange Co.", Iranian Accounting and Auditing Studies, $18^{\text {th }}$ edition, No. 63, pp. 95-112.

Agrawal, A. and Chandha, S. (2005). "Corporate governance and accounting scandals", SSRN Working Papers Series.

Ahmadpour, A; Kashanipour, M; Shojaei, M, (2010), "Study of effect of company governance and audit quality on financing through debt", Iranian Accounting and Auditing Studies, $17^{\text {th }}$ edition, No. 62, pp. 7-32.

Azizkhani , m , Gary S. Monroe, and Greg Shailer. (2013). "Audit partner tenure and cost of equity capital", Auditing. Practice \&Theory. 29(1) pp.73-97.

Baber, W.R.; Gore, A.K; Rich, K.T; and Zhang, J.X.(2010). "An empirical investigation of accounting restatements and governance in the 
municipal context", SSRN Working Papers Series, Pgs.50.

Ballesta, J.P.S; Garcia-Meca, E(2005). "Audit qualifications and corporate governance in Spanish listed firms", Managerial Auditing Journal, Vol. 20, No. 7, pp. 725-738.

Balsam, S., J. Krishnan, and J. S. Yang. (2003), "Auditor industry specialization and earnings quality", Auditing: A Journal of Practice \& Theory 22 2: 71-97.

Banimahd, B, (2011). "Study of effective factors on auditor's acceptable comments", Iranian Stock Exchange Market Quarterly, 4 (13), pp. 59-83.

Banimahd, B; Moradizadeh Fard, M; Zeinali, M, (2012). "Study of auditing fee on auditor's comment", Iranian Management Accounting Quarterly, $5^{\text {th }}$ year No. 15, pp. 41-54.

Banimahd, B; Moradizadeh Fard, M; Zeinali, M, (2013). "Relation between change of independent auditor and change of auditing comments", Iranian Accounting Knowledge Journal, $4^{\text {th }}$ year, No. 14, pp. 91-108.

Baqerpour Valashani, M; Saei, M.J; Meshkani, A; Baqeri, M, (2013). "Prediction of independent audit report in Iran, data search approach", Iranian Accounting Researches, No. 19, p 134-150.

Beattie, V. and Fearnley, S. (1998).Audit market competition: auditor changes and the impact of tendering. The British Accounting Review.30 (3):261-289.

Becker, C., Defond, M., Jiambalvo, J. and Subramanyam, K. (1998), "The effect of audit quality on earnings management", Contemporary Accounting Research, Vol. 15 No. 1, pp. 1-24.

Behn, B.K ${ }_{n}$ Choi, J.H., Kang, T (2008). "Audit quality and properties of analyst earnings forecasts", The Accounting Review (2) 83, pp. 349-327.

Bloomfield, D. and Shackman, J. (2008). "Non-audit service fees, auditor characteristics and earnings restatements", Managerial Auditing Journal Vol.23, No.2, pp.125-141.

Cao, Y.; Myers, L.A; and Omer, T.C. (2009). "Does company reputation matter for financial reporting quality? Evidence from restatements", SSRN Working Papers Series, Pgs61.

Carey P, Geiger, M; and O'Connel, B (2008). "Costs Associated With Going-Concern- Modified Audit Opinions: An Analysis of the Australian Audit Market, ABACUS, Vol. 44, No. 1.

Chen, G. Firth, M. Gao, D.N. and Rui. (2006). "Ownership structure, corporate governance, and fraud: Evidence from China", Journal of Corporate Finance12, pp. 424-448.

Chena, C., Lung G., and Fu-Hsing, C. (2009). "Strategic auditor switch and financial distress prediction, empirical findings from the TSElisted firms", Applied Financial Economics, 19: 59-72.

Chi, W; Douthett, E.B; and Lisis, L.L (2012). "Client importance and audit partner independence", Journal of Accounting Public Policy, No. 31, pp. 320-336.

DeAngelo, L.E, (1981)."Auditor size and audit quality". Journal of Accounting and Economics, 3(3). 183-189.

Dunn, K. and Mayhew, B.W. (2004). Audit firm industry specialization and client disclosure quality. Review of Accounting Studies, Vol. 9 No. 1, pp. 35-58.

Etemadi, H; Mohammadi, A; Nazemi Ardekani, M, (2009). "Study of relation between audit industry expertise and profit quality in the listed companies in Tehran Stock Exchange Market", Iranian Financial Accounting Researches Journal, 1st year, No. 1 and 2, p 17-32.

Etemadi, H, Azar A, Nazemi Ardekani, M, (2010). "Study of the role of audit industry expertise in realistic management of profit and future operational performance", Iranian Accounting Knowledge Journal, 1'st year, pp. 9-28.

Farber, D.(2005). "Restoring trust after fraud: Does corporate governance matter?", The Accounting Review, 80, 539-561.

Fernando,A; Abdel-Meguid, M.; Elder, R. J. (2010). " audit quality attributes, client size and cost of capital". Review of Accounting and Finance, Vol. 9 Iss: 4, pp.363 - 381.

Feroz, E., K. Park, and V. Pastena. (1991). "The financial and market effects of the SEC's accounting and auditing enforcement releases", Journal of accounting Research29 (Supplement): 107-142.

Geiger M.A., Raghunandan, K; and Rama, D.V. (2005). "Recent Changes in the Association between Bankruptcies and Prior Audit Opinions", Auditing: A Journal of Practice \& Theory, Vol. 24, No. 1, pp. 21.35.

Gul, F.A; Fung, S.Y.K; and Jaggi, B(2009). "Earnings quality: Some evidence on the role of auditor tenure and auditors' industry expertise, Journal of Accounting and Economics 47, pp. 265-287.

Habib, A. and Bhuiyan, M. and Borhan, U. (2011). "Audit firm industry specialization and the audit report lag g" Journal of International Accounting, Auditing and Taxation, 20: 32-44.

Hajiha, Z; Sobhani, N, (2012). "Study of effect of audit industry expertise on capital costs and interest rate of due amounts by the companies recognized in Tehran Stock Exchange Market", Iranian Accounting and Auditing Knowledge Management, 1st year, No. 3, pp. 35-46.

Hassasyeganeh, Y; Azinfar, K, (2010). "Relation between auditing quality and size of auditing organization", Iranian Accounting and Auditing Studies, $17^{\text {th }}$ edition, No. 61, pp. 85-95.

Hassasyeganeh, Y; Valizadeh Larijani, A and Ahmadi, A, (2012) "Study of effect of audit industry expertise on financial reporting and reaction of capital market" Iranian Stock Exchange Quarterly, No. 19, $5^{\text {th }}$ year, pp. 43-64.

Hassasyeganeh, Y, Mahmoudi, M, Panahi, S, (2013) "Study of effect of quality factors of auditing on assessment of management performance to explain created values for stockholders", $11^{\text {th }}$ national seminar of Accounting, Ferdowsi University, Mashhad.

Ireland, J. (2003). An empirical investigation of determinants of audit reports in the UK. Journal of Business Finance \& Accounting, 30(7 
\& 8), pp. 975- 1015.

Jamei, R; Helshi, M; Haji Eidi, A, (2012) "Study of effect of directors' performance on independent auditor's comments in the companies recognized by Tehran Stock Exchange Market", Iranian Studies of Accounting and Auditing, 19th edition, No. 4, pp. 1-14.

Javid, D; Soheili, H; Ahmadi, S; Angooti, S, (2013). "Expert auditors in one industry, external directors and financial analysts", the 11th national accounting seminar, Ferdowsi University, Mashhad.

Kend M. (2008)."Client industry audit expertise: towards a better understanding", Pacific Accounting Review, Vol. 20, pp. 49-62.

Kimberly A. Brian W .Mayhew. (2004). "Audit Firm Industry Specialization and Client Disclosure Quality". Review of Accounting Studies, 9, 35-58.

Krishnan, J; Krishnan, J; and Stephens (1996). "The simultaneous relation between auditor switching and audit opinion: An empirical analysis"; Accounting and Business Research, Vol. 26; Iss. 3; pp. 224-236.

Krishnan, G. V. (2003). Does Big 6 auditor industry expertise constrain earnings management? Accounting Horizons 17 (Supplement): $1-16$.

Li, C (2009). "Does Client Importance Affect Auditor Independence at the Office Level? Empirical: Evidence from Going-Concern Opinions", Contemporary Accounting Research, Vol 26, No.1, pp. 21-230.

Low, K(2004). "The Effects of Industry Specialization on Audit Risk Assessments and Audit-Planning Decisions", The Accounting Review, Volume 79, Iss. 1, pp. 201-219.

Maletta, M., and A. Wright. (1996). Audit evidence planning: An examination of industry error characteristics", Auditing: A Journal of Practice \& Theory 15 (1): 71-86.

Neal, T.L. and Riley, R.R. Jr (2004). "Auditor industry specialist research design", Auditing: A Journal of Practice \& Theory, Vol. 23 No. 2, pp. 169-77.

Nonahalnahr, A, Jabbarzadeh Kangarlouei, S, Pourkarim, Y, (2010). "Relation between auditing quality and reliability of withheld items", Iranian Accounting and Auditing Studies, $17^{\text {th }}$ edition, No. 61, pp. 55-70.

Owhoso, V. E., W. F. Messier, and J. G. Lynch. (2002). Error detections by industry-specialized teams during sequential audit review. Journal of Accounting Research 40 (3): 883-900.

Park. S.H., (1990) "Competition, Independence and Audit Quality: The Korean Experience", The International of Accounting, 25: (7186).

Payne, J.L(2008). "The Influence of Audit Firm Specialization on Analysts' Forecast Errors", AUDITING: A Journal of Practice \& Theory: November 2008, Vol. 27, No. 2, pp. 109-136.

Piri, P, Sheikhmohammadi, A; Javadi, N, (2013). "Study of relation between size of auditing institute an number of business owners of auditing institute of quality auditing", Iranian Auditing Knowledge, $13^{\text {th }}$ year, No. 51, pp. 5-24.

Reichelt, K.J; Wang, D(2010). "National and Office-Specific Measures of Auditor Industry Expertise and Effects on Audit Quality", Journal of Accounting Research, Vol 48, Iss. 3, pp. 647-686.

Rezaei, F; Mousavian, K, (2011). "Effect of characteristics of company on sustainability of members of the Board of Directors and independent auditor's comment", Iranian Experimental Accounting Researches, 1st year, No. 1, pp. 79-99.

Richardson, S., Tuna, Y; and Wu, M.(2002). "Predicting earnings management: The case of earnings restatements", SSRN Working Papers Series, Pgs. 41.

Romanus, R.N; Maher, J.J; and Fleming.(2008). "Auditor industry specialization, auditor changes, and accounting restatements", Accounting Horizons, Vol. 22, No.4, pp. 389-413.

Sajjadi, H; Zarradnejad, M; Jafari, A, (2009). "Non-Financial effective characteristics on quality of financial reporting in the companies recognized by Tehran Stock Exchange Market", Iranian Accounting and Auditing Studies, $16^{\text {th }}$ edition, No. 57, pp. 51-68.

Setayesh, M.H; Jamalianpour, M, (2009). "Study of relation between financial ratios and non-financial variables and auditor's comment", Iranian Accounting Researches, No. 2, pp. 130-157.

Shirinbakhsh, S, Arefmanesh, Z; and Bazrafshan, A. (2013) "Unequal information: Evidences about relation between governance and expertise of audit industry", Iranian Financial Accounting Experimental Studies Quarterly, $11^{\text {th }}$ year, No. 37, pp. 149-176.

Solomon, I., M. D. Shields, and O. R. Whittington. (1999). What do industry-specialist auditors know? Journal of Accounting Research 37 (1):191-208.

Stanley, J.D. and DeZoort, F.T.(2007). "Audit Firm tenure and financial restatements: An analysis of industry specialization and fee effects", Journal of Accounting and Public Policy26, pp.131-159.

Teoh, S.H; Wong, T.J.(1993). Perceived Auditor Quality and the Earning Response Coefficient. The accounting review. Vol 68.No 2.pp.346-365.

Vanstraelen, A. (2000). "Impact of renewable long-term audit mandates on audit quality", The European accounting review9(3), pp. 419442.

Wallace, W. (1980), The Economic Role of the Audit in Free and Regulated Markets, Monograph, Touche Ross \& Co, New York, NY. 